Gilberto Velho (1945-2012)

\section{Estudioso fundamental para a antropologia urbana no Brasil}

Desde a morte precoce de Gilberto Velho, com apenas 66 anos, muitos dos seus amigos, colegas e alunos têm externado seus tributos.

Todos concordam sobre certos aspectos da personalidade e da carreira científica de Gilberto: que ele foi fundamental na fundação e consolidação da antropologia urbana no Brasil; que agiu sempre no sentido de fortalecer as instituições científicas no país, desde o Programa de Pós-Graduação em Antropologia Social (PPGAS) do Museu Nacional, onde foi professor de 1970 até a sua morte, até a Associação Brasileira de Antropologia (ABA), a Associação Nacional de Pós-Graduação e Pesquisa em Ciências Sociais (Anpocs), das quais foi presidente, e a Sociedade Brasileira para o Progresso da Ciência (SBPC), da qual foi vice-presidente; que foi um brilhante professor; e que tinha um senso de humor absolutamente singular. Foi um orientador no sentido pleno do termo, sempre dedicado e exigente. Em mais de 40 anos de carreira, orientou quase 100 teses de doutorado e dissertações de mestrado. Seus ex-alunos brilham não apenas nas melhores

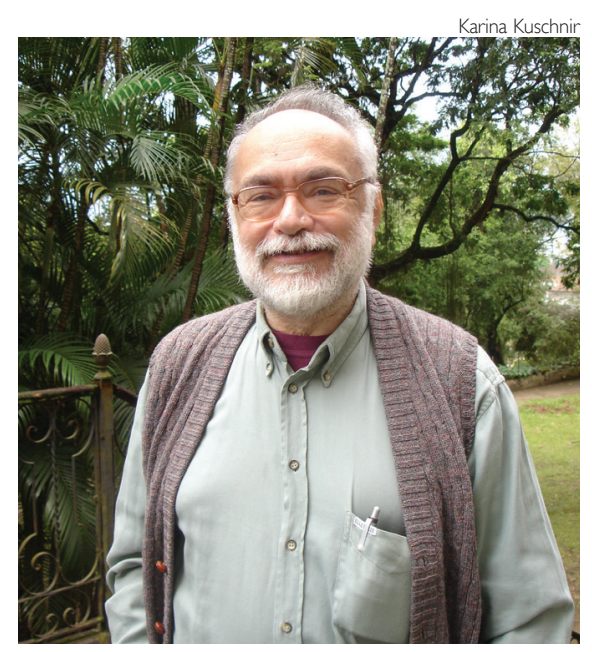

Gilberto Velho, durante entrevista para o projeto Cientistas Sociais Histórias de Vida

universidades do país e do mundo, como na televisão, no jornalismo e no mundo dos negócios.

Concordando com tudo isso, queria escrever aqui um pouco mais sobre sua contribuição importantíssima aos estudos do que se chamava na década de 1970 de desvio social. Uma de suas primeiras publicações, Desvio e divergência: uma crítica da patologia social (1974) é uma coletânea de textos escritos originalmente por seus alunos como trabalhos finais de curso (1). A obra é, ao mesmo tempo, prova da sua genialidade como professor, de seu compromisso com as carreiras de seus alunos e do seu pioneirismo em trazer o assunto do desvio para a antropologia brasileira, inspirado no interacionismo simbólico americano em geral e, especificamente, no trabalho do seu grande amigo Howard S. Be- cker. Nessa mesma época, comecei a escrever sobre homossexualidade e tive a honra de apresentar os meus primeiros resultados de pesquisa num seminário no Museu Nacional, a convite de Gilberto. Em 1975, ele já havia defendido sua tese de doutorado sobre o uso de drogas nas classes médias e altas do Rio de Janeiro, mais tarde publicada em livro - Nobres \& anjos: um estudo de tóxicos e hierarquia (1998). Gilberto deu um impulso de qualidade e legitimidade fundamentais aos estudos desses temas, antes tão malditos.

Acoplado a todo um compromisso social para com os seus alunos, amigos e o país que tanto amou, acompanhava-o um senso de humor que lhe era absolutamente peculiar. Os seus practical jokes eram notórios. Quantos de nós caíram nas suas "pegadinhas"? Estou convencido de que foi esse senso de humor que não o deixou nunca ficar chato e que aguçou a sua perspicácia analítica, fazendo dele um antropólogo de mão cheia e um querido amigo cuja falta será sentida por tantos e por muito tempo.

Peter Fry é professor aposentado do Departamento de Antropologia da Universidade Fe deral do Rio de Janeiro (UFRJ) e editor do jornal da Associação Brasileira de Antropologia, Vibrant - Virtual Brazilian Anthropology.

\section{NOTA}

1. Alguns se encontram no Vol.9, no.1 da revista Vibrant (www.vibrant.org.br) 